\title{
The Impact of Summer Reading on Young Learners' Foreign Language Acquisition
}

\author{
Ilona Kostikova ${ }^{1}$ \\ Olha Honcharova ${ }^{1}$ \\ Viktoriia Vorozhbit-Horbatiuk ${ }^{1}$ \\ Nataliia Soloshenko-Zadniprovska ${ }^{1}$ \\ Oleksandra Marmaza ${ }^{1}$ \\ Yuliia Lushchyk $^{2}$ \\ ${ }^{1}$ H.S. Skovoroda Kharkiv National Pedagogical University, Ukraine \\ ${ }^{2}$ Sumy National Agrarian University, Ukraine
}

Doi: 10.36941/jesr-2020-0o22

\begin{abstract}
Absrtact
The aim of the research was to solve a problem of sustaining and developing foreign language skills and abilities by young learners during long-lasting summer holidays. The analysis of the current situation in Ukrainian education sector showed that reading a book continues to be one of the few tools for English revision in summer. There has been little research targeting on studying the impact of summer reading on young learners' foreign language acquisition, so the experiment in which 240 young learners (aged 8-9) took part was conducted. Both the experimental $(n=120)$ and control $(n=120)$ groups were pre-tested and posttested in May and September 2019 respectively, and the children's skills and abilities in reading comprehension, vocabulary, speaking, writing and creativity were checked. The data obtained before the experiment showed almost the similar level of language acquisition in both groups. The results of the experiment indicated significant progress of the participants of the experimental group in every aspect of English. The main factors which played the crucial role in young learners' enhancements were access to English readers, comprehensibility of the reading materials which were elaborated specially for the children's language needs, interesting topics, reading for pleasure and enjoyment without tasks, tests or marks, and parental support. These results proved the reasonability of integrating summer reading in teaching foreign languages in primary school and induced the creation of English readers for all grades of elementary education.
\end{abstract}

Keywords: foreign language acquisition, primary school, summer reading, young learners.

\section{Introduction}

Owing to the wide-reaching integration processes and entire globalization of sciences, economics, industry, trade and technologies, worldwide significance of the English language as the means of international communication has been constantly growing. According to EF English Proficiency 
Index (2018), which is the world's most authoritative ranking of countries and regions by English skills, Ukraine due to government language policy heightened its score notably in 2018 comparing to the previous year and was transferred from a low proficiency group into a cluster with moderate abilities, though it is true to say that at present time it embraces last but one rating place in its group. Notwithstanding the apparent progressing in English acquisition, there is still a considerate proficiency gap between Ukraine and other European countries, with an average score 13 points below the European Union as a whole. The strong desire to improve language skills so as to access international collaboration in various domains, and recognition of the utmost importance of language learning in modern societies provoke both Ministry of Education and Science of Ukraine and Ukrainian teachers of English to design effective and efficacious learning strategies.

\subsection{The New Ukrainian School}

The recent modernization of Ukrainian education sector commenced in 2017 when the new Law on Education was adopted; as a consequence, the period of schooling has been lengthened from 11 up to 12 years, new standards of education have been accepted, and school programmes have been updated (Law on Education, 2017). The pervasive ideology of the extensive transformations expecting school education is delineated in the Ministry document 'The New Ukrainian School. Conceptual principles of secondary school reform' (2016), in which communication in foreign languages holds next to number-one position of communication in the national language among 10 basic skills, that coincides with the standpoint of the European Commission stating that "language competences will play a key role in creating a European Education Area" (Proposal for a Council Recommendation, 2018).

The implementation of the Law launched from the first school level in September 1, 2018 and foresees that "the quality of education, in particular, in foreign languages, will be increased" (The New Ukrainian School, 2016, p. 21). Thus, the overall percentage of primary school learners starting to learn a foreign language from grade 1 (age 6) has achieved its absolute maximum of 100 percent. In accordance with the new State Standard of Primary Education (2018), the foreign language as the compulsory school subject occupies 70 academic hours in the $1^{\text {st }}$ grade, or 2 hours per week, and 105 hours in the $2^{\text {nd }}-4^{\text {th }}$ grades, or 3 hours per week. The Education Program on Foreign Languages in Primary School (2018) claims that by the end of the $4^{\text {th }}$ year young learners of general education institutions reach the level of $A_{1}$, while learners of specialized schools with in-depth study of foreign languages attain Az level on the CEFR (Common European Framework of Reference).

\subsection{Problem of Research}

Despite the government achievements in language learning policy and English teachers' efforts throughout the educational process, there is a widely recognized problem of sustaining the language skills by young learners (Kostikova, Gulich, Holubnycha, \& Besarab, 2019), particularly during longlasting summer holidays. It is one of the most urgent challenges for teachers of English as a paramount feature of young learners is their capacity "to acquire the language and forget it with equal ease" (Harmer, 2007, p. 15). The point is that in the course of holiday time, which endures in Ukraine for full three months (precisely, from 31 May till 31 August), primary school learners are released from home tasks and, consequently, from revising the language material in any form; besides that, the vast majority of young learners do not attend language schools and camps nor have private English lessons. As for the online and digital tools for language acquisition, Ukraine still demonstrates low e-skills of its population and needs further school digitalizing, including content renewal (Kostikova, 2019), general access to online resources, and re-education of teacher staff (Digital agenda for Ukraine, 2016).

On the basis of the points mentioned above, the reading approach appears to be one of the few available, effective and productive ways to develop, or at least sustain young learners' knowledge of English obtained during the academic year. 
In the methodology of teaching English as a second language it has sometimes been claimed that ability to read and comprehend comes naturally from any communicative language experience, i.e. during speaking, listening, or writing, thus focusing on speaking and listening at most and using reading and writing exercises as a supplementary language activity. However, the impact of reading should not be underestimated as it is the key to the effective communication; without the ability to comprehend and understand the text effectively, messages can be interpreted in a wrong way that impedes and hinders successful communicative achievement. Moreover, even if a young learner is able to read words and phrases in a foreign language properly, it does not necessarily mean the ability to read comprehensively as it involves greater range of skills.

Being a complex, multi-level, interdisciplinary phenomenon, reading comprehension has always been a focal point of research by scholars in different fields who have attempted to understand the nature and mechanisms of this complicated issue through the prism of their subject knowledge.

\subsection{Research Focus}

The importance of reading in any language, which a person tends to acquire, has long been discussed and proved in numerous investigations. Regular reading either in the mother tongue or a second or foreign language has positive influence not only on language learning progress, but it also fosters the development of learner's personality (Bright \& McGregor, 1970; Brusch, 1991; Elley \& Mangubhai, 1983; Krashen, 1981; 2004; 2011) and has "a significant effect on children's literacy" as a whole (Morrow, 1995, p. 7).

Education researchers (Bright \& McGregor, 1970; Brusch, 1991; Elley \& Mangubhai, 1983; Harmer, 2007; Krashen, 2011; N'Namdi, 2005) use different terms for defining out-of-school reading, among them are 'extensive reading', 'independent reading', 'voluntary reading', 'private reading', 'recreational reading', 'leisurely reading', 'reading for pleasure', 'joyful reading' etc. Despite the variety of descriptions, all of the definitions accentuate the point that extensive reading (as the opposition to intensive reading in class) is a supplementary activity which aims to entertain, amuse and enjoy the reader. To achieve the goal this form of reading should engage real-life topics and problems directly related to the child, and to what that child believes to be important (N'Namdi, 2005; Ruddell \& Unrau, 1997). According to Krashen (1981; 2011), the language of the EFL readers should be understandable enough, or even one level higher learners' linguistic competence that will induce the learner to use the textual context thoughtfully.

Also, it should be "not only comprehensible, but also 'compelling' or highly interesting" (Krashen, Lee, \& Lao, 2017). Cho and Krashen outline the following conditions for organizing successful reading practice, "1. An initial pleasant reading experience. 2. Access to interesting reading material. 3. A time and place to read regularly. 4. The freedom to select own reading. 5. No tests, no workbook exercises and no rewards for reading" (Cho \& Krashen, 2016).

While Cho and Krashen's statements are acceptable in general, yet it must be pointed out that in practice there is still a problem with the access to reading materials of high quality in the vast majority of the Ukrainian schools, let alone the possibility to make personal choice of the book. Both school libraries and English classrooms, especially those located in rural area, experience deficiency of modern and age-graded resources. Somewhat better state of affairs can be observed in urban specialized schools, where the EFL readers are provided exclusively at the expense of students' parents. Kemba A. N'Namdi claimed that learners should be supplied with books, which "they need to create interest and stimulate the desire to read", and in case there is a lack of such materials, it is the responsibility of a teacher to generate them (N'Namdi, 2005, p. 32). Indeed, the fact that reluctant readers are mostly children with little access to books has been acknowledged by a number of researchers (Morrow, 1995; Shin \& Krashen, 2008).

All in all, the importance and meaningfulness of extensive reading, including summer leisure reading, have been profoundly explored, though it is worth noticing that the mainstream of researches specify reading English as the mother tongue, or as the language of schooling (Elley \& 
Mangubhai, 1983; N'Namdi, 2005), while a number of works which examine reading EFL emphasize predominantly secondary and high school students (Brusch, 1991; Krashen, 2011). Likewise, little to nothing experimental inquiries considering summer reading in primary school and its effects on preserving and developing of EFL skills have been carried out. So, the current research is expected to broaden the knowledge about the reading approach employed in primary school and help elaborate potent strategies for upgrading and intensifying EFL teaching in Ukraine.

The aim of the research was to take a new look at leisure-time reading as an efficient method able to stimulate primary school pupils' learning interest and preserve their EFL skills over the period of lengthy summer break in schooling.

Hypothesis. The home reading over summer holidays was expected to support, or even improve young learners' EFL skills; and the accessibility and comprehensibility of the reading material, as well as corresponding to children's age content and design of the book, were believed to play crucial role in the experiment.

It was also assumed that parents' collaborative involvement in the reading session (such as unobtrusive arrangement of time and place for reading, shared reading, discussions, reading aloud), would have positive impact on children's motivation to read, speak and write English. For that reason the following recommendations for parents, which they received at the end of the academic year (May, 2019) before the experiment started, were elaborated:

1. Organize regular reading sittings in a cosy and quiet place. The time of the day depends on individual preferences of the child and can be in the morning or in the evening alike.

2. Encourage the child to read aloud for parents or grandparents, for sisters and brothers if there are any, for his (her) toys and pets.

3. Considering audiovisual idiosyncrasy of young generation, you can propose your child to make a mobile video recording of his (her) reading aloud for further sharing with friends and relatives in social networks. The satisfying recording may demand several reading attempts that is itself a great contribution into improving language skills.

4. Involve your child in a reading competition to find out who reads faster, louder (or quieter), more expressively and artistically etc.

5. Activate the language in an unpretentious way by asking such questions as "Who's (What's) that (in the picture)?" "Do you like today's story?" "Would you like to draw your present for Liz / a postcard for grandmother / write a poem?" etc.

6. Let your son (daughter) return to the texts which he (she) has already read if the child wants to reread them.

7. Never force the child to read. Instead, if he (she) is tired or unwilling to read, let him (her) have a rest or engage another activity.

8. Never punish the child with reading!

\section{Research Methodology}

In accordance with the purpose of the research empirical methods such as observation, discussion, testing, and an experiment in order to analyse the results of developing language skills and statistical methods to evaluate the results of the experiment were used.

The pedagogical experiment was carried out in Kharkiv schools, Ukraine, in summer 2019 with young learners who apart from the curriculum course of their English during the academic year were given the optional author's Home Reading Book for summer reading. The experimental group included 120 young learners (age 8-9 years old, $3^{\text {rd }}-4$ th grades). The control group included 120 young learners as well, but they were not supplied with the Home Reading Book and were not proposed to read during their summer holidays. The analysis of the level of formation of the certain language and speech skills before (May, 2019) and after (September, 2019) the experiment using the same tasks and activities was conducted. The gender differences were not explored in this research.

For the purpose of this research and in order to supply young learners with summer readers, 
which would correspond to all above-mentioned principles and requirements and guarantee the sufficient comprehension, the book 'We Read English' by Olha Honcharova, 2018 (ISBN: 978-966935-532-4) was created. The story with throughout characters, who were the peers of the primary school learners, related their everyday deeds and experiences such as schooling, family and home matters, friendship, team collaboration, joys and phobias, pet caring etc.

The book comprised 43 separate texts of 150 to 350 words which covered all the themes and topics designated in the national education program on foreign languages for 3-4 grades, namely Family and Friends, Pets and Wild Animals, Hobbies and Leisure (sports, playing computer games, cooking, drawing, writing poetry, collecting), Seasons and Weather, School (school environment, timetable, lessons, science project), Holidays and Festivities (birthday, costume and end-of-year parties, Christmas celebration, summer holidays and summer camp).

Among the genres, there were diary notes and notes written for friends, texts with dialogues, direct speech and self-talk of a first-person narrator, math word problems, phone massages, a timetable, birthday and Christmas cards, poems, a recipe, summer camp schedule, an invitation for a birthday party and a questionnaire, which also provided supplementary models for real-life communication.

The carefully chosen language material was focused on the linguistic competences adopted for Ukrainian primary school and engaged young learners' relevant knowledge of grammar tenses and structures (Present Simple, Present Continuous, Future Simple, I can / can't..., Let's..., I've got / $\mathrm{He}$ (She)'s got, imperative sentences etc.).

The vocabulary of the book implied both active and potential lexical items; the latter embraced international words which were similar in form to those ones in the learners' native language (e.g. yoga, president, supermodel, soldier, figurine, album, badminton, museum, information etc.), compound words which young learners were able to understand due to familiar part(s) (windowsill, sunglasses, snowflake, classmates, headphones, everybody, hide-and-seek, lazy-bones, roller-skate, good-humoured, end-of-year), and the words the meaning of which could be guessed through the context.

Acknowledging that different children may have different discovery abilities while identifying the word meaning, and aiming to avoid or at least minimize the mother tongue interference, some of the lexical items were semantized through the paginal images.

Finally, the storybook was densely illustrated with motivating colourful pictures which besides the esthetical and entertaining functions were supposed to help children comprehend the language material in full. In addition to that, different formats of letters were used so as to focus young readers' attention on the text, namely uppercase for titles and those words which needed logical stress to express the emotions felt by the characters, italics for inner speech, and bold shift for words explained in a pictorial way.

\section{Research Results}

Data obtained at the end of the academic year showed that both groups had practically similar level of language acquisition. After the participants of the experimental group read regularly the proposed book during summer holidays, they demonstrated positive dynamics in sustaining their knowledge of English and further developing of all relevant language and speech skills: reading comprehension, vocabulary, speaking, writing, and creativity. The listening skills were not measured.

At the end of the pedagogical experiment the young learners of both groups were offered to check reading comprehension in the test using the tasks: answer the questions, fill in the gaps, match, define if the statements are true or false, choose the correct answer, and complete the sentences.

In the control group the results were not as high as for the previous test at the beginning of the experiment: results in grey are before the experiment, results in black are after the experiment (Figure 1). 


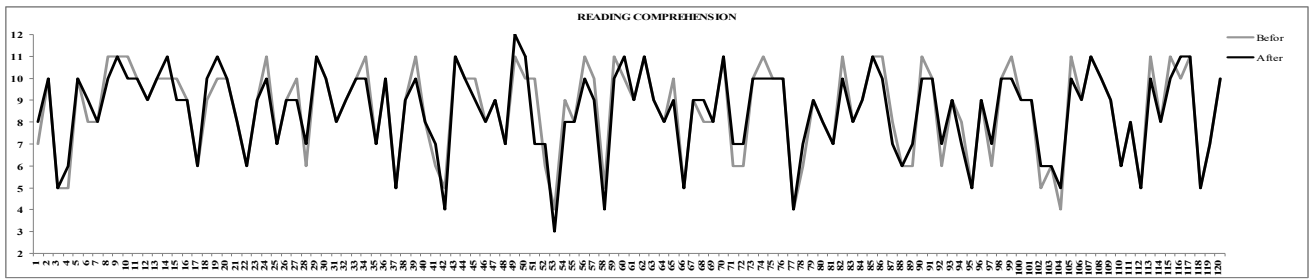

Figure 1: The results before (in grey) and after (in black) the experiment in the control group in reading comprehension

In the experimental group the results were higher as for the previous test at the beginning of the experiment: results in grey are before the experiment, results in black are after the experiment (Figure 2).

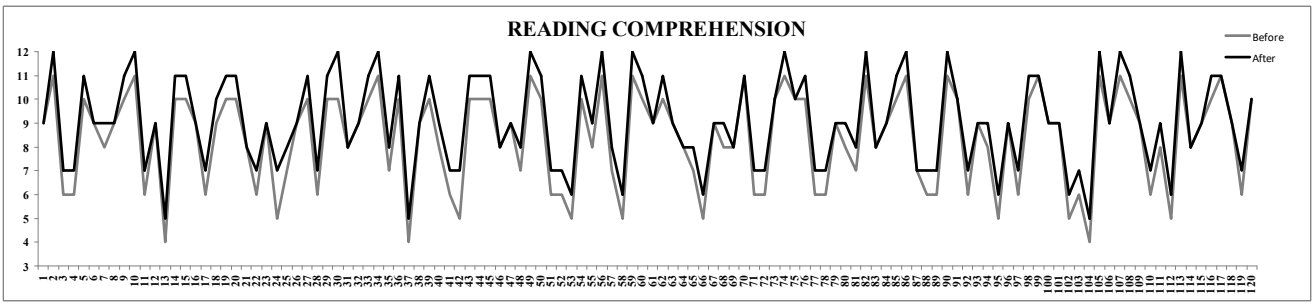

Figure 2: The results before (in grey) and after (in black) the experiment in the experimental group in reading comprehension

At the end of the experiment other skills were checked as it was hypothesized that reading comprehension could influence on other skills and abilities: vocabulary, speaking, writing, and creativity.

The comparison in vocabulary as for the tasks fill in the gaps, match the word and the picture, choose the correct answer, complete the sentence, find words with similar (opposite) meaning of the control and experimental groups (before and after the experiment) are shown in Figure 9.
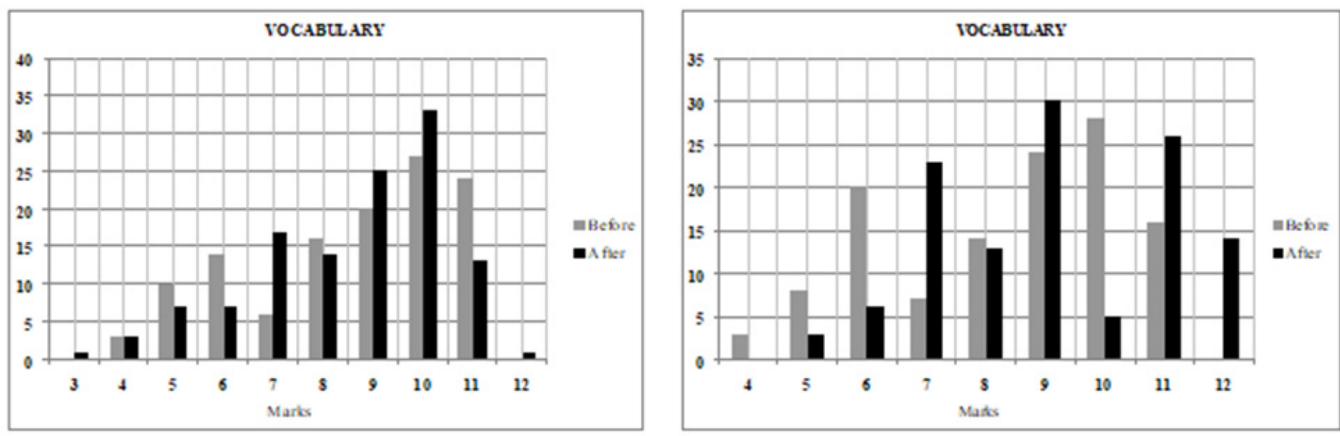

Figure 3: The results before and after the experiment in the control (the left-hand figure) and experimental (the right-hand figure) groups in vocabulary

The comparison in speaking as for the tasks talk about your family, give personal information, talk 
about your neighborhoods, describe your house / room, tell about your pet, talk about your daily routine, talk about your leisure time, tell what you like and dislike, ask your partner about..., finish the story of the control and experimental groups (before and after the experiment) are shown in Figure 4.
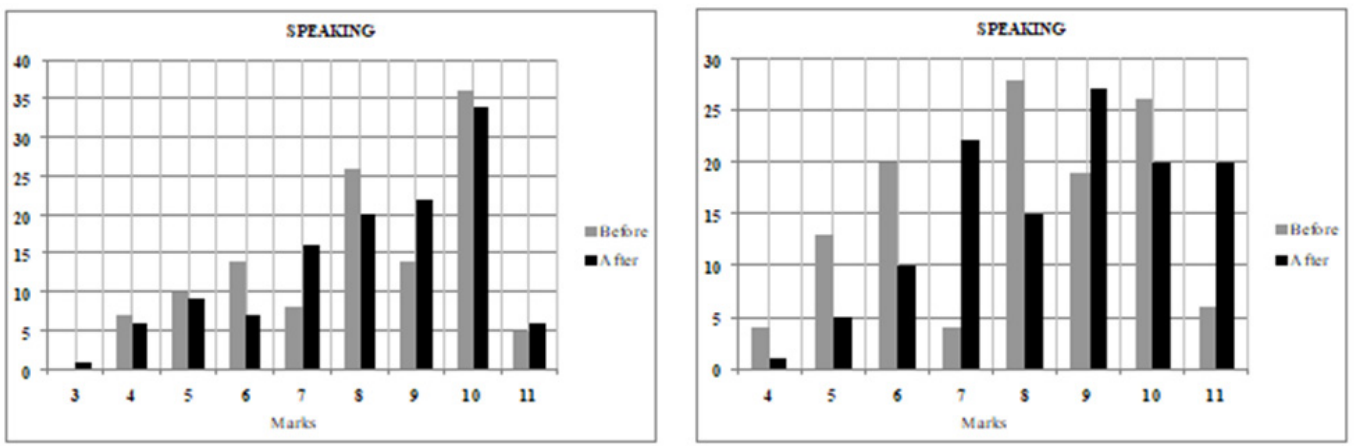

Figure 4: The results before and after the experiment in the control (the left-hand figure) and experimental (the right-hand figure) groups in speaking

The comparison in writing comprised checking of both writing for learning and writing as a skill. In the case of the former, the tasks as fill in the missing letter (word), put the words in the correct order to make a sentence, fill in the missing pronouns, write the plurals, write a sentence for each word were used. Activities which were used for measuring writing skills included the following ones: fill in the form, complete the postcard, write an invitation using the model, write a phone (e-mail) massage, write about your family (friend, pet, hobbies), describe your room (house, school), write about your day routine, answer the questionnaire. The results of the control and experimental groups (before and after the experiment) are shown in Figure 5.
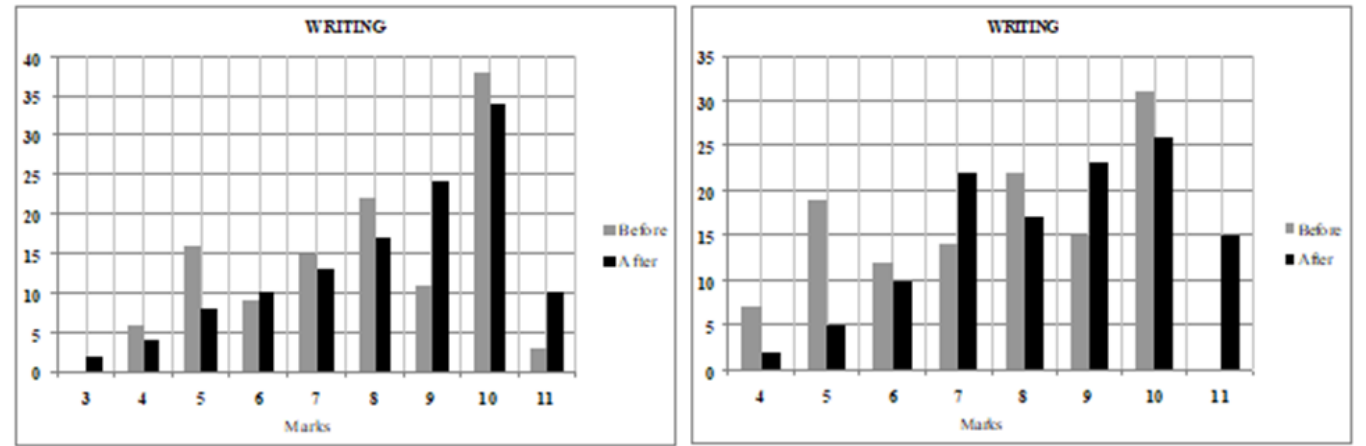

Figure 5: The results before and after the experiment in the control (the left-hand figure) and experimental (the right-hand figure) groups in writing

The comparison in creativity as for the tasks create (tell or write) your own end of the story, create your own poetry, create a postcard to ..., create an invitation to ..., create a poster about..., create a project about ... of the control and experimental groups (before and after the experiment) are shown in Figure 6. 

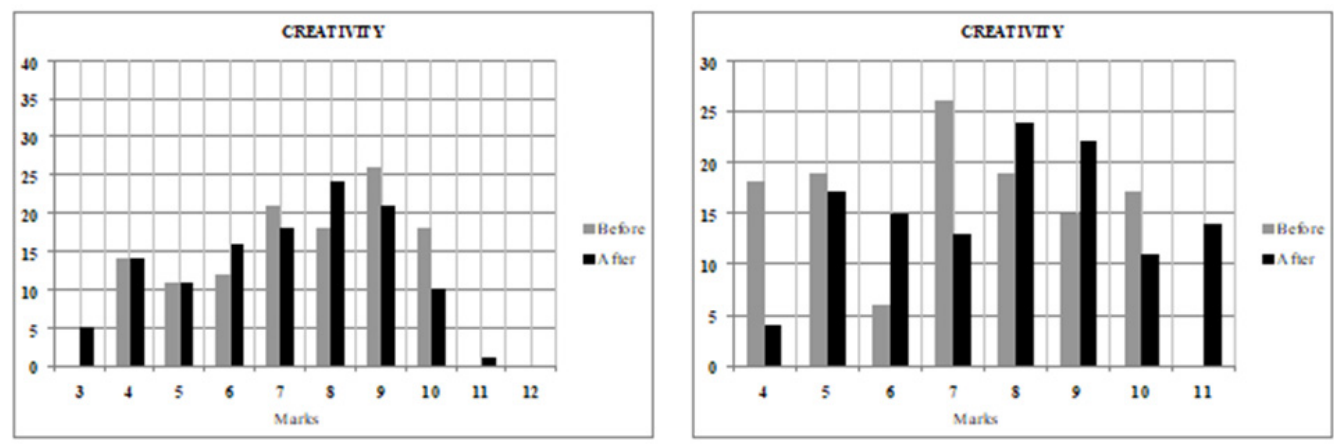

Figure 6: The results before and after the experiment in the control (the left-hand figure) and experimental (the right-hand figure) groups in creativity

Summarized results of the final tests in the experimental group showed the increase of reading comprehension and the improvement of other young learners' English skills after conducting the pedagogical experiment. The results proved that summer reading for pleasure had real influence on sustaining of the young learners' English vocabulary in their long-term memory and had positive impact on their speaking, writing and creativity.

The analysis of the figures demonstrate that, firstly, the majority of young learners in the experimental group improved results in reading comprehension; secondly, the young learners showed better results in vocabulary, speaking, writing and creativity if compared with the results of the control group.

It is indicative that participants of the experimental group enhanced their English vocabulary the most. It may be explained by the fact that the book 'We Read English' was elaborated specially for the needs of Ukrainian primary school learners, with consideration of the national education program requirements, and, consequently, was chiefly based on active school vocabulary. Also, it confirms that the methods of semantization of new words used in the book were suitable for the children's age and appropriate to their language level. Thus, summer home reading for pleasure is the efficient tool for vocabulary revision and learning new words.

Also, the young learners of the experimental group showed significant attainment in creativity. From our point of view, it implies that the learners of the $3^{\text {rd }}$ grade had little experience in transforming their ingenious ideas into final results, and that the book which was proposed for summer reading provided them with extra models and templates for their own inventive activity.

All in all, young learners' progress in English skills allows us to claim that the general achievement of the experimental group is significant, which proves the statistical importance of the results obtained in this study. The results of the experiment are connected precisely with that circumstance that summer reading encouraged the young learners to read with pleasure, to be interested in English during summer holidays, to improve English skills unconsciously, to have a positive attitude for continuing learning English; besides, summer reading stimulated real-life interaction. It would be necessary to accentuate children's high motivation determined by the fact that they read exclusively for enjoyment without any tasks, testing or marks. Also, the parents' devotion to the research and their practical assistance during summertime should be considered, as it, undoubtedly, had a great affect on the results of the experiment.

\section{Discussion}

The experiment confirmed and extended the existing knowledge of other researchers concerning the role of reading for pleasure in the process of a foreign language acquisition. Krashen in his 
monograph 'Principles and Practice in Second Language Acquisition' (1982) claims that the limitations of the language classroom ought to be overcome in order to give the students opportunity to use a foreign language outside and make the transition to the real world possible. Among the alternative methods, Dr. Krashen points out 'pleasure reading' as the efficacious means of language acquisition. However, the scholar reasonably notes that there is a risk in making pedagogical materials for leisurely reading excessively complicated and overburdened with infrequent grammar and vocabulary, and insists on voluntary choice of the books by students according to their interests and language level. As it was demonstrated in our research, the above-mentioned dangers were completely overcome in the specially designed book for summer reading. As for the requirement about reader's own selection of the texts (Brusch, 1991; Cho \& Krashen, 2016; Harmer, 2007; Krashen, 1982; 2004; 2011), which is entirely true for high school students, or secondary school students, it is our firm belief that primary school learners, as well as their parents engaged in the child's learning process, need teacher's advice and assistance in choosing reading materials, and, as the experiment showed, greet being provided with ones.

This research alongside the experience of other scholars (Brusch, 1991; Elley \& Mangubhai, 1983; Harmer, 2007; Ruddell \& Unrau, 1997; Shin \& Krashen, 2008; Wilson, 2019) emphasizes the effectiveness of extensive reading in a foreign language for upholding learners' motivation, reinforcing real-life interaction, and improvement of all academic skills and abilities as well. Obviously, leisure reading, including reading in summer, stimulates young learners' involuntary memory; as a result, they enlarge their vocabulary, enhance spelling, acquire grammar structures unconsciously, develop reading comprehension, gain speaking and writing skills in an inconspicuous way.

\section{Conclusions and Perspectives of Further Research}

As the experiment has demonstrated, the summer reading has a positive impact on young learners' ability to maintain their English language skills over the lengthy summer holidays and motivates their further foreign language acquisition. Mastering the ability to read and comprehend effectively and to read for pleasure in summertime is a complex, challenging, dynamic process that requires integration of appropriate reading skills, abilities, attitudes, knowledge, and behaviours in order to get the advance in this field. Such a difficulty can be attributed to the variety of factors described in this article. However, the author's book proposed for reading during summer holidays, which covers the range of models for real-life communication, and parents' support implemented in the experiment, contributed extensively to the young learners' progress in studying English. The perspective aim thus is to elaborate English readers for all stages of primary education, as well as to deepen the cooperation with the young learners' parents, that together could raise the foreign language teaching to a much higher level.

\section{References}

Brusch, W. (1991). The role of reading in foreign language acquisition: Designing an experimental project. ELT Journal, Volume 45(2), 156-163. Retrieved 2019, September 16, from http://eltj.oxfordjournals.org/ http://citeseerx.ist.psu.edu/viewdoc/download?doi=10.1.1.831.9609\&rep=rep1\&type=pdf.

Cho, K. S. \& Krashen, S. (2016). What does it take to develop a long-term pleasure reading habit? Turkish Online Journal of English Language Teaching (TOJELT), 1(1), 1-9. Retrieved 2019, September 16, from http://www.sdkrashen.com/content/articles/2016_cho_and_krashen_long-term_reading.pdf.

EF English Proficiency Index. (2018). Retrieved 2019, June 9, from https://www.ef.com/ca/epi/.

Elley, W. \& Mangubhai, F. (1983). The impact of reading on second language learning. Reading Research Quarterly, 19, $53-67$.

European Commission. (2018). Proposal for a Council Recommendation on a comprehensive approach to the teaching and learning of languages [Online]. Retrieved 2019, June 9, from https://eur-lex.europa.eu/legalcontent/EN/TXT/?uri=COM\%3A2018\%3A272\%3AFIN. 
Harmer, J. (2007). How to teach English. Edinburgh: Pearson Education Limited.

Honcharova, O.A. (2018). Chytayemo anhliiskoyu. [We Read English]. Kharkiv, Ukraine: Unisoft.

Kostikova I., Gulich, O., Holubnycha, L., \& Besarab, T. (2019). Interactive whiteboard use at English lessons: from university students to young learners. Revista Espacios, 40 (12). Retrieved 2019, June 9, from http://www.revistaespacios.com/a19v40n12/19401210.html.

Kostikova, I. (2019). Challenges of playing games at English lessons. Online Book of abstracts of the III International scientific and practical Internet conference "Foreing language in professional training of specialists: Issues and strategies” (pp. 125-127). Kropyvnytskyi, Ukraine: EPC of Volodymyr Vynnychenko Central Ukrainian State Pedagogical University. Retrieved 2019, June 9, from https://www.cuspu.edu.ua/images/conferences/2019/mo2/maket_2019.pdf.

Krashen, S. (1981). Second language acquisition and second language learning. Oxford: Pergamon Press.

Krashen, S. (1982). Principles and Practice in Second Language Acquisition. University of Southern California [Online]. Retrieved 2019, September 16, from http://www.sdkrashen.com/content/books/principles_and_practice.pdf.

Krashen, S. (2004). The Power of Reading. Portsmouth, NH: Heinemann and Santa Barbara: Libraries Unlimited.

Krashen, S. (2011). Free voluntary reading. Westport: Libraries Unlimited.

Ministry of Economic Development and Trade of Ukraine. (2016). Digital agenda for Ukraine - 2020 [Online]. Retrieved 2019, September 16, from http://www.e-ukraine.org.ua/media/Lviv_Minich_2.pdf.

Ministry of Education and Science of Ukraine. (2016). The New Ukrainian School. Conceptual principles of secondary school reform [Online]. Retrieved 2019, September 16, from https://mon.gov.ua/storage/app/media/zagalna\%2oserednya/Book-ENG.pdf.

Ministry of Education and Science of Ukraine. (2017). Law on Education [Online]. Retrieved 2019, September 16, from https://mon.gov.ua/ua/npa/law-education.

Ministry of Education and Science of Ukraine. (2018). Derzhavny standard pochatkovy osvity. [State standard of primary education.] Retrieved 2019, June 9, from https://www.kmu.gov.ua/ua/npas/pro-zatverdzhennyaderzhavnogo-standartu-pochatkovoyi-osviti.

Ministry of Education and Science of Ukraine. (2018). Navchalna prohrama dlya zahalnoosvitnyh ta spetsyalizovanyh navchalnyh zakladiv. 1-4 klasy. [Foreign languages. Education program for secondary and specialized schools. 1-4 grades.] Retrieved 2019, June 9, from https://mon.gov.ua/storage/app/media/zagalna\%2oserednya/programy-14-klas/inozemna-mova-poyasnyuvalna-znz-sznz-1-4-klas-belyaeva-xarchenko-finalna-zv.pdf.

Morrow, L.M. (1995). Family literacy: new perspectives, new practices. In: L.M.Morrow (ed.), Family Literacy Connections in Schools and Communities (pp. 5-10). Newark, Del., International Reading Association.

N'Namdi, K.A. (2005). Guide to teaching reading at the primary school level. Paris: UNESCO. Retrieved 2019, September 16, from https://files.eric.ed.gov/fulltext/ED495644.pdf.

Renandya, W.A., Jacobs, G.M., Krashen, S.D. \& Min, C. Ong Hui (2019). The Power of Reading: Case Histories of Second and Foreign Language Readers. Language and Language Teachings, 8, 1(15), 10-14. Retrieved 2019, September 16, from http://www.sdkrashen.com/content/articles/renandya_et_al_case_histories._2019.pdf.

Ruddell, R. B. \& Unrau, N. J. (1997). The role of responsive teaching in focusing reader intention and developing reader motivation. In: J.T.Guthrie and A.Wigfield (eds), Reading Engagement: Motivating Readers through Integrated Instruction (pp. 102-127). Newark, Del., International Reading Association.

Shin, F.H. \& Krashen, S.D. (2008). Summer reading: program and evidence. Pearson Education.

Wilson, R. (2019). Nurturing Reading Success in Young Learners of English [Online]. Retrieved 2019, June 9, from https://ngl.cengage.com/infocus/index.php/2019/o3/27/nurturing-reading-success-in-young-learners-ofenglish/. 